\title{
Analisis Pengelolaan Zakat, Infak, Dan Sedekah (ZIS) \\ Untuk Meningkatkan Ekonomi Duafa \\ (Studi Kasus di Lembaga Amil Zakat Nurul Hayat Cabang Medan )
}

\author{
Nazlah Khairina \\ Perguruan Islam Al-Amjad \\ Zlahfat@gmail.com
}

\begin{abstract}
This study aims to analyze the way LAZ Nurul Hayat collects ZIS funds and to analyze how the distribution of ZIS by Nurul Hayat in improving duafa economists, to analyze how the strategy carried out by LAZ Nurul Hayat in improving the economy of the poor. The research methodology is using the qualitative research with descriptive approach. Data collection techniques were carried out by in-depth interviews and documentation. The data analysis techniques are done by reducing, presenting data and drawing conclusions. The results of this study indicate that how to collect Zakat, Infaq, Sedekah funds is in three ways, namely amil coming to the place of muzaki, muzaki transferring funds to Nurul Hayat and the last one is muzaki coming directly to Nurul Hayat's office. Efforts in the distribution of ZIS in Nurul Hayat were carried out by direct survey of mustahik who were programmed to be given assistance, by choosing two categories, which were worthy of special assistance and worthy of assistance. The strategy carried out by Nurul Hayat is by monitoring the development of business carried out by mustahik who are given ZIS funds by monitoring and guiding if there are difficulties in developing their business.
\end{abstract}

Keywords: Management, Zakat, Infak, Sedekah, Improve, Duafa Economy

\begin{abstract}
Abstrak
Penelitian ini bertujuan untuk menganalisis cara LAZ Nurul Hayat dalam menghimpun dana ZIS dan untuk menganalisis bagaimana cara pendistribusian ZIS oleh Nurul Hayat dalam meningkatkan ekonom duafa, untuk menganalisis bagaimana strategi yang dilakukan LAZ Nurul Hayat dalam meningkatkan ekonomi duafa. Adapun metodologi penelitian ini adalah menggunakan penelitian kualitatif dengan pendekatan deskriptif. Teknik pengumpulan data dilakukan dengan wawancara mendalam dan dokumentasi. Sedangkan teknik analisis data dilakukan dengan cara reduksi, penyajian data dan penarikan kesimpulan. Hasil penelitian ini menunjukkan bahwa cara menghimpun dana Zakat, Infak, Sedekah ialah dengan tiga cara yaitu amil datang ke tempat muzaki, muzaki mentransfer dana ke Nurul Hayat dan yang terakhir muzaki mendatangi langsung ke kantor Nurul Hayat. Upaya dalam pendistribusian ZIS di Nurul Hayat dilakukan dengan cara survei langsung para mustahik yang di programkan untuk diberi bantuan, dengan memilih dua katagori yaitu layak dibantu dan layak dibantu secara khusus. Strategi yang dilakukan Nurul Hayat adalah dengan cara pemantauan perkembangan usaha yang dilakukan oleh mustahik yang diberi dana ZIS dengan cara mengawasi dan membimbing apabila terjadi kesulitan dalam mengembangkan usahanya.
\end{abstract}

Kata Kunci : Pengelolaan, Zakat, Infak, Sedekah, meningkatkan, Ekonomi Duafa 


\section{Pendahuluan}

Perekonomian menjadi salah satu hal yang sangat dinantikan oleh seseorang maupun lembaga atau instansi pemerintah. Perekonomian sangat berperan penting dalam kehidupan dikarenakan jika rendahnya ekonomi seseorang maka biasanya taraf kehidupannya pun juga rendah. Sebaliknya jika tingginya perekonomian seseorang biasanya taraf kehidupan seseorang tersebut juga tinggi. Dengan demikian, dalam kehidupan ini tidak bisa terlepas dari persoalan perekonomian. Permasalahan ekonomi selalu tidak pernah habisnya untuk dibahas karena berhubungan dengan angka kemiskinan. Kemiskinan menjadi hal yang sangat ditakuti oleh setiap orang karena kemiskinan berdampak kepada permasalahan multidimensional berupa pendidikan, sosial, kesehatan, dan politik.

Permasalahan ekonomi adalah hal yang krusial bagi kehidupan baik secara individu, masyarakat dan negara. Kesejahteraan dan ketenteraman hidup suatu negara dapat dilihat dari gambaran ekonomi masyarakatnya. Dalam perekonomian tidak jauh dari kata-kata keuangan. Keuangan merupakan alat yang sangat vital bagi kehidupan seseorang. Biasanya keuangan identik dengan harta dan dengan harta identik dengan sudut pandang orang yang menilai miskin ataupun kaya. Biasanya kaum yang tidak bisa mencukupi kehidupannya disebut duafa atau fakir miskin. Dalam Hal ini sangat mendorong seseorang yang berlebihan harta untuk berbagi dengan orang lain. ${ }^{1}$

Salah satu cara yang dapat meningkatkan perekonomian dan masalah kemiskinan adalah dengan memperdayakan umat melalui Zakat, Infak dan Sedekah. Cara ini merupakan salah satu solusi untuk mengurangi masalah perekonomian seperti kemiskinan. Zakat, infak dan sedekah memiliki potensi yang besar jika digunakan sebagai pemberdayaan umat. Apabila potensi dana ZIS dapat dikelola dengan baik oleh pengelola badan amil zakat maupun lembaga amil maka kemiskinan akan semakin berkurang setiap tahunnya. Zakat, infak, dan sedekah menjadi instrumen ekonomi yang memiliki kekuatan atau efek domino dalam pengentasan kemiskinan, pembukaan lapangan pekerjaan baru, pendapatan dan daya beli kaum duafa, mendorong tumbuhnya perekonomian masyarakat. ${ }^{2}$ Selain itu, ZIS juga dapat mengatur sistem ekonomi, individu, masyarakat, dan negara. Zakat, infak, sedekah memiliki potensi untuk dikembangkan secara ekonomi. Jika dilihat dari pertumbuhannya, zakat mengalami perkembangan yang 
pesat, khususnya pada satu dakade terakhir. Akan tetapi pertumbuhan zakat tersebut masih sangat jauh dari potensi zakat sebenarnya. ${ }^{3}$ Potensi yang begitu besar dikarenakan adanya penduduk mayoritas yang beragam muslim. Jika penduduknya semua muslim akan tetapi kesadaran untuk membayar zakatnya masih kurang maka potensinya tidak bisa tercapai.

Menurut Badan Pusat Statistik penduduk Indonesia merupakan salah satu negara dengan mayoritas penduduk muslim berjumlah 207. 176.162 (juta) jiwa atau angka absolutnya 207,2 (juta) jiwa atau mencapai $87,13 \%{ }^{4}$. Dengan jumlah umat muslim yang begitu besar, maka potensi dana zakat di Indonesia juga begitu besar. Dalam penelitian Firdaus, menyebutkan bahwa potensi zakat nasional pada tahun 2011 mencapai angka 3,4 persen dari total PDB, atau dengan kata lain potensi zakat di Indonesia diperkirakan mencapai Rp 217 triliun. Jumlah ini meliputi potensi penerimaan zakat dari berbagai area, seperti zakat di rumah tangga, perusahaan swasta, BUMN, serta deposito dan tabungan. Sedangkan menurut penelitian BAZNAS, potensi zakat nasional pada tahun 2015 sudah mencapai Rp 286 triliun. Angka ini dihasilkan dengan menggunakan metode ekstrapolasi yang mempertimbangkan pertumbuhan PDB pada tahun-tahun sebelumnya dengan asumsi potensi zakat nasional akan meningkat setiap tahunnya. ${ }^{5}$ Meskipun demikian, potensi zakat di Indonesia begitu besar akan tetapi kurang di dukung dengan keadaan di lapangan yaitu pencapaian dalam penghimpunan dana zakat, infak, dan sedekah. Penghimpunan zakat, infak dan sedekah nasional oleh OPZ (organisasi Pengelola Zakat) resmi pada tahun 2015 yang baru mencapai Rp 3,7 triliun atau kurang dari 1,3 persen potensinya. ${ }^{6}$ Sementara pada tahun 2016 penghimpunan dana ZIS nya baru terhimpun 5 triliun. Artinya realisasi penghimpunan dana zakat, infak dan sedekah masih jauh dari potensi yang dimiliki. Hal ini disebabkan karena beberapa faktor yaitu kurangnya kesadaran masyarakat dalam menunaikan kewajibannya untuk berzakat, masih kurangnya pengetahuan terhadap zakat, dan masih kurangnya kepercayaan masyarakat terhadap Badan amil zakat (BAZNAS) maupun lembaga amil zakat (LAZ)

Seiring dengan potensi dana ZIS di Indonesia begitu juga dengan di Sumatera Utara khususnya, penduduk muslim di Sumatera Utara sekitar 1.422.237 jiwa $^{7}$ atau 0,68\% dari jumlah penduduk Indonesia yang diperkirakan memiliki potensi zakat sebesar 2 Triliun. Akan tetapi dugaan dari 2 Triliun 
dananya hanya mencapai 84,2 Miliar atau setara dengan $4,21 \%{ }^{8}$ Hal ini sangat jauh dengan potensi yang ada. Jika potensi itu digarap dengan baik, maka penduduk miskin di sumatera utara akan semakin berkurang.

Hal inilah ZIS sebagai salah satu alternarif untuk berkurangnya penduduk miskin menambah peningkatan dan perkembangan ekonomi masyarakatnya. Karena zakat, infak dan sedekah secara bertahap akan memberikan dampak positif untuk menghilangkan kemiskinan dan mengurangi perputaran harga pada segelintir orang. Sebagai dampaknya, pekerjaan dan pendapatan akan meningkat dalam perekonomian sehingga meningkatkan standar hidup dari orang-orang dan akhirnya akan meningkatkan volume agregat zakat. ${ }^{9}$ Zakat, infak dan sedekah (ZIS) sangat berpengaruh dalam pertumbuhaan dan pembangunan ekonomi serta tingkah laku ekonomi manusia maupun masyarakat. ${ }^{10}$ Selain itu (ZIS) sebagai komponen penting dalam perekonomian kurang diperhatikan oleh individu, lembaga amil zakat, maupun pemerintah. Hal ini bisa jadi dari sistem pengelolaan baik dari Lembaga Amil Zakat sendiri maupun dari kurangnya pengetahuan masyarakat tentang zakat. Dengan begitu setiap orang harus mengetahui kewajiban dalam menunakan peran zakat, infak dan sedekah dalam kemashalahatan umat.

Berkaitan dengan itu, pengaruh zakat, infak dan sedekah terhadap peningkatan ekonomi terutama pertumbuhannya juga telah banyak diuji. Kajian di Malaysia menunjukkan adanya pengaruh positif penerapan zakat, infak dan sedekah terhadap pertumbuhan ekonomi oleh Muhammad B.Yusuf pada periode 2006-2009. ${ }^{11}$ Di Pakistan juga ditemukan bahwa zakat, infak dan sedekah memiliki dampak positif pada pembangunan ekonomi di Pakistan. Lebih khusus, zakat, infak dan sedekah secara signifikan terhadap pertumbuhan ekonomi di Pakistan. $^{12}$

Badan Pusat Statistik (BPS) mencatat pada September 2016, penduduk miskin per September 2016 mencapai 28,51 juta orang atau 11,13\% dari total jumlah penduduk Indonesia. Karena itu zakat memiliki peran penting yang diharapkan dapat membantu menekan angka kemiskinan di Indonesia. ${ }^{13}$ Sedangkan pada penduduk miskin di Sumut pada September 2017 sebanyak 1.326,57 ribu orang $(9,28 \%)$, turun sebesar 0,94 poin dibandingkan persentase penduduk miskin Maret 2017 yang berjumlah 1.453,87 ribu orang (10,22\%). 
Walaupun angka ini turun 0,94 persen yang artinya penurunan ini masih harus ditingkatkan lagi karena masih banyaknya jumlah penduduk miskin.

Dasar tujuan dari zakat, infak dan sedekah tidaklah sekedar menyantuni orang miskin secara konsumtif, tetapi mempunyai tujuan yang lebih permanen yaitu mengentaskan kemiskinan. ${ }^{14}$ Namun sampai saat ini zakat, infak dan sedekah belum mampu meningkatkan kesejahteraan bagi umat, terutama mustahik (orang yang berhak menerima zakat, infak dan sedekah). Menurut UndangUndang No 23 Tahun 2011 tentang pengelolaan zakat, infak dan sedekah pada Bab 1 Pasal 3 tujuan dari zakat, infak dan sedekah ialah ayat (1) meningkatkan efektivitas dan efisiensi pelayanan dalam pengelolaan zakat, infak dan sedekah (2) meningkatkan manfaat zakat, infak dan sedekah untuk mewujudkan kesejahteraan masyarakat dan penanggulangan kemiskinan. ${ }^{15}$

Berdasarkan latar belakang di atas, penulis tertarik untuk mengadakan penelitian dalam bentuk dengan judul "Analisis Pengelolaan Zakat, Infak, dan Sedekah( (ZIS) Untuk Meningkatkan Ekonomi Duafa tahun 2017 (Studi Kasus di Lembaga Amil Zakat Nurul Hayat Cabang Medan)” dengan rumusan masalah dalam penelitian ini adalah :

1. Bagaimana cara LAZ Nurul Hayat untuk menghimpun Dana ZIS dari masyarakat?

2. Bagaimana upaya amil zakat dalam mendisribusikan zakat untuk meningkatkan ekonomi duafa?

3. Bagaimana strategi meningkatkan ekonomi duafa yang dikelola oleh Nurul Hayat?

\section{Landasan Teori}

\section{Zakat}

Zakat berasal dari kata "az-zakah" yang dalam bahasa arab. Kata "azZakah" memiliki beberapa makna, di antaranya "an-numuww” (tumbuh), "azziyadah" (bertambah), "ath-thaharah" (bersih), "al-madh" (pujian), "albarakah" (berkah) dan "ash-shulh" (baik). ${ }^{16}$ Adapun secara terminologis adalah sejumlah harta tertentu yang diwajibkan Allah diserahkan kepada orang-orang yang berhak menerima. Adapun pengertian zakat menurut beberapa para ahli ialah sebagai berikut: 
1. Menurut Yusuf Qardhawi, zakat adalah sejumlah harta tertentu yang diwajibkan Allah untuk diserahkan kepada orang-orang yang berhak menerimanya. ${ }^{17}$

2. Abdurrahman al-Jaziri berpendapat bahwa zakat adalah penyerahan kepemilikan tertentu kepada orang yang berhak menerimanya dengan syaratsyarat tertentu pula. $^{18}$

3. Muhammad Al-Jarjani dalam bukunya Al-Ta'rifat mendefiniskan zakat sebagai suatu kewajiban yang telah ditentukan Allah bagi orang-orang islam untuk mengeluarkan sejumlah harta yang dimiliki. ${ }^{19}$

4. Menurut Sayid Sabiq zakat adalah sesuatu harta yang harus dikeluarkan manusia sebagai hak Allah untuk diserahkan kepada fakir miskin, disebut zakat karena dapat memberikan keberkahan, kesucian jiwa, dan berkembangnya harta. ${ }^{20}$

\section{Landasan Dasar Zakat dalam Al-Quran dan Hadist}

\section{Landasan Al-Quran}

Di dalam al-Quran, Allah Swt telah menyebutkan secara jelas berbagai ayat tentang zakat dan shalat berjumlah 82 ayat. Dari sini disimpulkan bahwa zakat merupakan rukun Islam terpenting setelah shalat. Zakat dan shalat dijadikan sebagai perlambang keseluruhan ajaran Islam dan juga dijadikan sebagai satu kesatuan. Pelaksaaan shalat melambangkan hubungan seseorang dengan Tuhan, sedangkan pelaksanaan zakat melambangkan hubungan antar sesama manusia. ${ }^{21}$ Beberapa ayat Al-Quran yang menjelaskan tentang zakat di antaranya Q.S alBayyinah, ayat :5

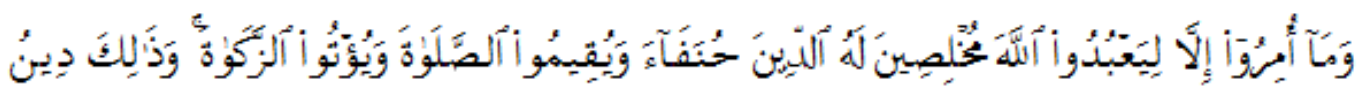

"Padahal mereka tidak disuruh kecuali supaya menyembah Allah dengan memurnikan ketaatan kepada-Nya dalam (menjalankan) agama yang lurus, dan supaya mereka mendirikan shalat dan menunaikan zakat; dan yang demikian Itulah agama yang lurus ${ }^{, 22}$ 


\section{Landasan Hadis}

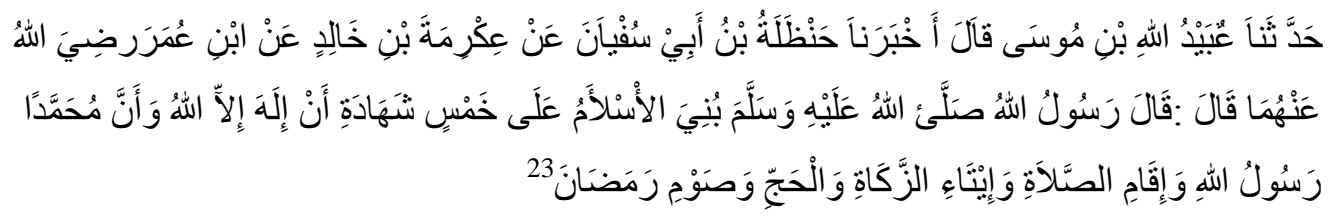

"Ubaidullah bin Musa menceritakan kepada kami, ia berkata, Hanzhalah bin Abi Sufyan memberitahukan kepada kami dari Ikrimah bin Khalid dari Ibn Umar ia berkata : Rasulllah Saw, bersabda : Islam didirikan atas lima sendi: Mengaku bahwa tidak ada Tuhan selain Allah dan Muhammad adalah utusan Allah, mendirikan shalat, mengeluarkan zakat, mengerjakan haji dan berpuasa di bulan Ramadhan.

Hadis di atas menjelaskan kesepakatan semua (ulama) umat Islam di semua negara tentang diwajibkan zakat. Bahkan para sahabat Nabi Ra. sudah bersepakat untuk memerangi orang-orang yang tidak mau mengeluarkan zakat. Karena zakat merupakan hal yang paling sering dilupakan oleh orang lain untuk dikeluarkan melalui hartanya. Barangsiapa yang belum mengetahui tentang hukum wajibnya, lantaran tidak tahu sebab baru saja memeluk Islam, atau sebab dia hidup di suatu tempat yang jauh dari kalangan ulama, maka dia harus diberi tahu tentang hukum wajibnya. Dan dia tidak dihukumi sebagai orang kafir, karena dia berudzur. ${ }^{24}$

\section{Infak}

Infak berasal dari kata "anfaqa" yang artinya keluar, yang berarti mengeluarkan sesuatu harta untuk kepentingan sesuatu yang tujuannya untuk mendapatkan ridho Allah. ${ }^{25}$ Sedangkan menurut terminologi syariat, infak berarti mengeluarkan sebagian harta atau pendapatan/penghasilan untuk sesuatu yang diperintahkan ajaran Islam. Jika zakat ada nishabnya, infak tidak mengenal nishab. Infak juga sebahagian kecil dari harta yang digunakan untuk kebutuhan orang banyak sebagai kewajiban yang dikeluarkan karena atas dasar keputusan diri sendiri. ${ }^{26}$ Pengertian dari infak juga merupakan sesuatu yang dibelanjakan untuk kebaikan. Infak juga tidak memilki batas waktu untuk begitu juga dengan besar dan kecilnya. Akan tetapi infak biasanya identik dengan harta yaitu sesuatu yang diberikan untuk kebaikan. Jika ia berinfak maka kebaikan akan kembali kepada dirinya sendiri, jika tidak melakukan infak maka tidak jatuh kepada dosa. ${ }^{27}$

Sedangkan menurut Undang-Undang Republik Indonesia Nomor 23 Tahun 2011 tentang Pengelolaan Zakat, Infakadalah harta yang dikeluarkan oleh seseorang atau badan diluar zakat untuk kemaslahatan umum. ${ }^{28}$ 
Seperti pada ayat Al-Quran Surah Ali Imran : 134
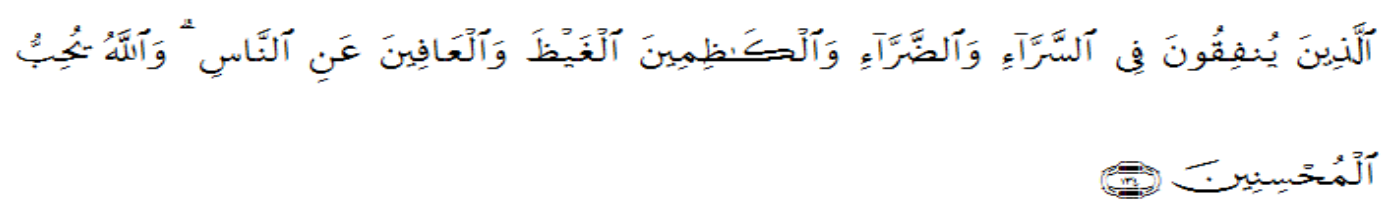

“(Yaitu) orang-orang yang menafkahkan (hartanya), baik di waktu lapang maupun sempit, dan orang-orang yang menahan amarahnya dan mema'afkan (kesalahan) orang. Allah menyukai orang-orang yang berbuat kebajikan "29

Dalam ayat di atas dijelaskan bahwa infak tidak ditetapkan waktunya seperti zakat. Infak dikeluarkan oleh setiap orang yang beriman, baik yang berpenghasilan tinggi maupun rendah. Jika zakat harus diberikan kepada mustahik tertentu (8 asnaf) maka infak boleh diberikan kepada siapa pun juga, misalnya untuk kedua orang tua, anak yatim dan sebagainya.

\section{Sedekah}

Sedekah berasal dari kata shadaqah, yang berarti jujur atau benar. ${ }^{30}$ Orang yang suka bersedekah adalah orang yang benar pengakuan imannya. Menurut terminologi syariat, pengertian sedekah sama dengan pengertian infak, termasuk juga hukum dan ketentuan-ketentuannya. Hanya saja, jika infak berkaitan dengan materi, sedekah memiliki arti lebih luas, menyangkut hal yang bersifat non materiil. ${ }^{31}$ Adapun anjuran tentang bersedekah seperti dalam Al-Quran Surah AlBaqarah :254

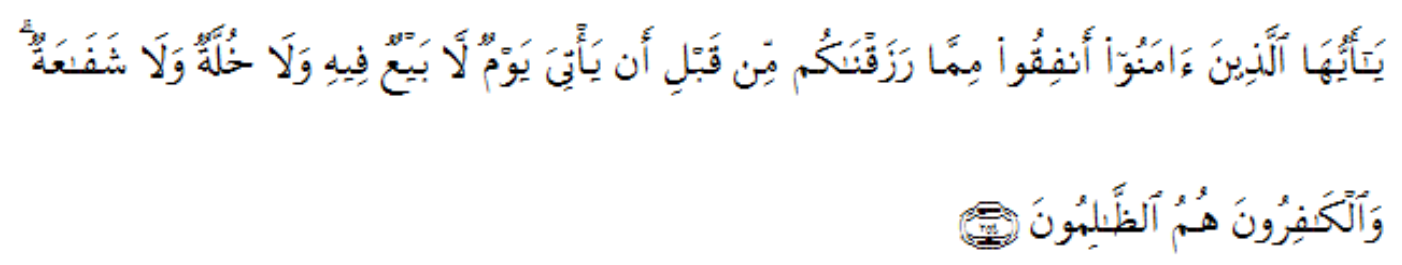

"Hai orang-orang yang beriman, belanjakanlah (di jalan Allah) sebagian dari rezki yang telah Kami berikan kepadamu sebelum datang hari yang pada hari itu tidak ada lagi jual beli dan tidak ada lagi syafa'at. dan orang-orang kafir Itulah orang-orang yang zalim, 32

Dalam ayat ini Allah menyuruh kita untuk sering bersedekah sebelum terjadinya hari kiamat yang tidak ada jual beli. Sedekah bisa memberikan dan 
mendatangkan syafaat ketika di akhir kelak bagi orang sering bersedekah. Baik sedekah fisik maupun materi keduanya akan mendapat pahala yang sama.

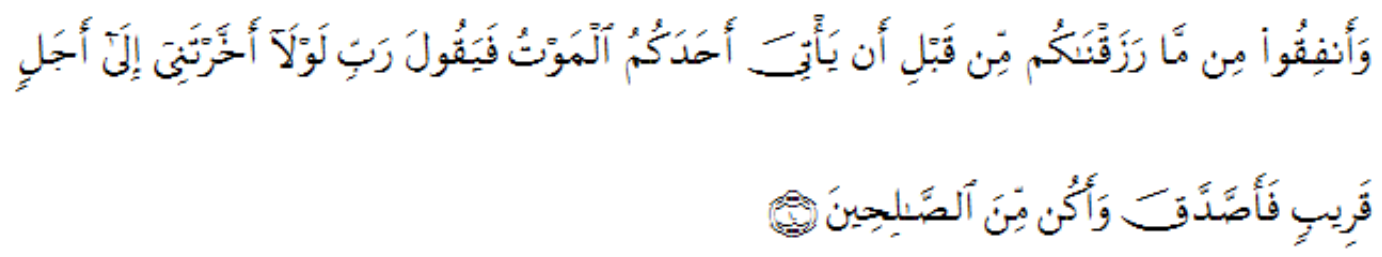

Dan belanjakanlah sebagian dari apa yang telah Kami berikan kepadamu sebelum datang kematian kepada salah seorang di antara kamu; lalu ia berkata: "Ya Rabb-ku, mengapa Engkau tidak menangguhkan (kematian)ku sampai waktu yang dekat, yang menyebabkan aku dapat bersedekah dan aku Termasuk orangorang yang saleh?" ${ }^{33}$

\section{Orang yang Berhak Menerima Zakat}

Orang yang berhak menerima zakat sesuai dengan syariat Islam berdasarkan Quran Surah. At-Taubah : 60, yaitu :

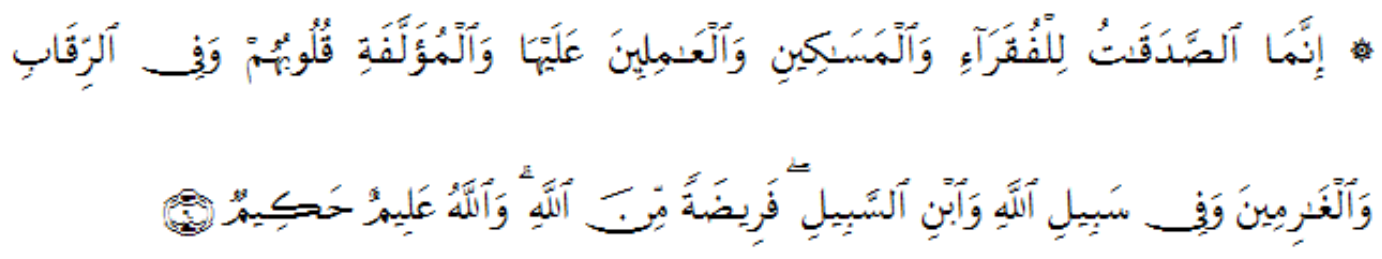

"Sesungguhnya zakat-zakat itu, hanyalah untuk orang-orang fakir, orang-orang miskin, pengurus-pengurus zakat, Para mu'allaf yang dibujuk hatinya, untuk (memerdekakan) budak, orang-orang yang berhutang, untuk jalan Allah dan untuk mereka yuang sedang dalam perjalanan, sebagai suatu ketetapan yang diwajibkan Allah, dan Allah Maha mengetahui lagi Maha Bijaksana”. (At-taubah $: 60)^{34}$

Ayat ini menjelaskan tentang peruntukan kepada siapa zakat itu diberikan. Para ahli tafsir menguraikan kedudukan yang berbeda, baik dalam kuantitas, kualitas, maupun perioritas. ${ }^{35}$

\section{Orang-orang Fakir dan Miskin}

Fakir adalah mereka yang tidak berharta serta tidak memiliki usaha yang tetap dalam rangka untuk mencukupi kebutuhan hidupnya. Selain itu, mereka yang dikategorikan sebagai orang yang fakir juga tidak memiliki pihak-pihak 
yang menjamin kehidupannya selama ini. Adapun yang dimaksud dengan miskin adalah orang-orang yang tidak dapat mencukupi kebutuhan hidupnya, meskipun selama itu ia memiliki pekerjaan ataupun usaha yang tetap. Kebutuhan di sini bukan hanya kebutuhan primer, akan tetapi juga kebutuhan sekunder. Akan tetapi, para ulama secara umum menegaskan bahwa mereka yang dikategorikan sebagai fakir dan miskin pada dasarnya adalah mereka yang tidak memiliki kemampuan materi, dengan ciri-ciri di bawah ini :

a. Kemampuan materi nol atau kepemilkian aset yang nihil

b. Memiliki aset property dalam jumlah yang sangat minim

c. Memiliki aset keuangan yang kurangi dari nisab

d. Mereka yang tidak dapat memanfaatkan kekayaaanya karena berada jauh dari tempat tinggalnya juga dapat dikategorikan sebagai orang yan tidak mampu secara materi.

2. Amil Zakat atau Pengumpul Zakat

Amil adalah mereka yang diangat oleh pihak yang berwenang yang diberikan tugas untuk melaksanakan berbagai kegiatan yang berkaitan dengan urusan zakat. Termasuk dalam hal ini adalah mengumpulkan dana zakat serta membagikannya kepada para mustahik penerima dana zakat. Pihak yang ditunjukkan sebagai amil zakat diharapkan sebagai pihak yang tidak perlu diragukan kejujurannya, karena dana zakat yang menjadi bagian dari amil tidak boleh langsung diambil oleh para petugas amil, akan tetapi harus mendapatkan persetujuan dari atasan para petugas tersebut. Adapun tugas utama para amil dalam menyalurkan zakat adalah:

a. Menarik zakat dari para muzaki

b. Mendoakan ketika muzaki menyerahkan zakatnya

c. Mencatat zakat dengan benar (diserahkam oleh muzaki)

d. Mengatur pembagian zakat dengan benar dan adil

e. Menyalurkan zakat kepada yang berhak menerimanya. ${ }^{36}$

\section{Mualaf}

Mualaf adalah mereka yang baru masuk Islam, yang diharapkan kecenderungan hatinya atau keyakinannya dapat bertambah terhadap Islam, atau terhalangnya niat jahat mereka atas kaum muslimin atau harapan akan adanya kemanfaatan mereka dalam membela dan menolong kaum muslimin. 


\section{Riqab (Budak)}

Riqab budak merupakan orang-orang yang kehidupannya dikuasai secara penuh oleh majikannya. Islam telah melakukan berbagai cara untuk menghapuskan tindakan perbudakan di dalam masyarakat. Di antaranya sebagian dari dana zakat digunakan untuk memerdekan budak. Meskipun penggunakan dana zakat untuk ini sudah lama dihapus, akan tetapi selagi tujuannya yang tidak bertentangan dengan tujuan yang sama diperbolehkan. Misalnya membantu para buruh untuk membuat kerajinan sehingga bisa menjadi pemilik industri.

\section{Gharim (Orang yang berhutang)}

Gharim adalah orang yang mempunyai utang, da ia tidak mempunyai kelebihan dari utangnya. Termasuk dalam kategori ini adalah pertama, orang yang berhutang untuk kepentingan pribadi yang tidak bisa dihindarkan dengan syaratsyarat sebagai berikut: Utang itu tidak timbul karena kemaksiatan, utang itu melilit pelakunya, si pengutang sudah tidak sanggup lagi melunasi utangnya, utang itu sudah jatuh tempo, atau sudah harus dilunasi ketika zakat itu diberikan kepada si penghutang. Kedua, Orang-orang yang berhutang untuk kepentingan sosial, seperti yang berhutang untuk mendamaikan antara pihak yang bertikai dengan memikul biaya denda kriminal atau biaya barang-barang yang dirusak. Ketiga, Orang-orang yang berhutang karena menjamin utang orang lain dimana yang menjamin dan yang dijamin keduanya berada dalam kondisi kesulitan keuangan. $^{37}$

6. Fisabillah (Berjuang di jalan Allah)

Fisabillah adalah orang berjuang di jalan Allah dalam pengertian luas sesuai dengan yang ditetapkan oleh para ulama fiqih. Intinya adalah melindungi dan memelihara agama serta meninggikan kalimat tauhid ${ }^{38}$, orang yang berjihad di jalan Allah, bila terjadi peperangan dan untuk kepentingan kemaslahatan bersama seperti mendirikan mesjid, membuat jembatan, memperbaiki jalan-jalan dan lain-lain.

7. Ibnu Sabil

Seseorang yang berada dalam perjalannya yang tidak mempunyai bekal untuk memenuhi kebutuhannya dalam perjalannya. Kelompok-kelompok yang sasaran zakat tersebut pada umumnya kaum lemah yang memerlukan perlindungan di bidang ekonomi. Ini menunjukkan bahwa Islam mempunyai 
komitmen yang tinggi terhadap kaum lemah terhadap apapun, termasuk lemah di bidang ekonomi, karena orang lemah tidak mampu mewujudkan eksistensi dirinya sebagai khalifah (wakil) Allah di muka bumi dan sebagai hamba yang harus mengabdi kepadanya. ${ }^{39}$

\section{Peran Zakat dalam Peningkatan Ekonomi}

Ada beberapa pendapat para ahli tentang peningkatan ekonomi. Biasanya peningkatan ekonomi juga sering diartikan dengan pertumbuhan ekonomi.

1. Menurut Karjoredjo, pertumbuhan ekonomi adalah proses kenaikan pendapatan masyarakat di suatu daerah dalam jangka panjang. Pendapatan masyarakat di sini lebih ditekankan pada pendapatan riil dan pendapatan masyarakat perkapita orang. ${ }^{40}$

2. Menurut Sukirno, pertumbuhan ekonomi adalah perkembangan kegiatan ekonomi yang berlaku dari waktu ke waktu dan menyebabkan pendapatan nasional riil semakin berkembang. ${ }^{41}$

3. Menurut Prasetyo, pertumbuhan ekonomi dapat diartikan sebagai kenaikan kapasitas produksi barang dan jasa secara fisik dalam kurun waktu tertentu. ${ }^{42}$

Sementara menurut peneliti sendiri peningkatan adalah proses, cara, perbuatan untuk menaikkan sesuatu atau usaha kegiatan untuk memajukan sesuatu ke suatu arah yang lebih baik lagi daripada sebelumya. Jadi peningkatan ekonomi adalah cara atau perbuatan untuk menaikkan berkembangan usaha yang tujuannya adanya perubahan peningkatan ekonomi pada waktu tertentu. Dalam kaitan peningkatan ekonomi, maka peranan zakat juga harus memiliki peranan aktif dalam sektor perekonomian. Sistem zakat mempunyai peranan aktif dalam perekonomian. Karena zakat merupakan pungutan yang mendorong kehidupan ekonomi hingga terciptanya pengaruh-pengeruh tertentu. ${ }^{43}$ Integrasi zakat dalam menentukan kebijakan ekonomi nasional sangatlah diperlukan. Apalagi secara teoritis, aplikasi zakat dalam kehidupan perekonomian akan memberikan sejumlah implikasi penting. Berdasarkan Qur'an Surah Al-Baqarah ayat 275-281, ada tiga sektor penting dalam perekonomian menurut al-Qur'an, yaitu: ${ }^{44}$

1. Sektor riil (al-bay), yaitu bisnis dan perdagangan.

2. Sektor keuangan atau moneter, yang diindikasikan oleh larangan riba.

3. Zakat, infak dan sedekah (ZIS) 
Sebagai pilar ketiga dalam perekonomian zakat, infak, dan sedekah memiliki fungsi yang sangat penting dalam pertumbuhan ekonomi. Ini tercermin pada dua konsep utama,yaitu pertumbuhan ekonomi berkeadilan dan mekanisme sharing dalam perekonomian. Tujuan utamanya adalah untuk meningkatkan kesejahteraan kaum duafa. Pada jangka pendek, kebutuhan mustahik dapat terpenuhi, sementara pada jangka panjang, daya tahan ekonomi mereka akan meningkat. Zakat adalah salah satu institusi terpenting dalam kerangka sosialekonomi Islam. Dalam Al-Qur'an, perintah shalat juga sering kali diikuti dengan perintah zakat. Hal ini secara jelas menyiratkan betapa pentingnya zakat yang berdimensi (habluminannas) yang disetarakan dengan shalat yang berdimensi (habluminallah). ${ }^{45}$

Dampak zakat atas kemaslahatan masyarakat dan perekonomian Islam sangatlah jelas. Karena dalam zakat itu sendiri terdapat unsur pemberian bantuan kepada orang-orang fakir, disamping mewujudkan kepentingan yang bersifat umum. Ini dapat dilihat secara jelas dari pos-pos pendistribusian zakat. Dengan zakat berarti kekayaan itu didistribusikan dari kalangan orangorang kaya kepada orang-orang fakir. Dengan cara seperti ini, maka terdapat unsur pemerataan kekayaan, sehingga kekayaan tidak menggelembung di pihak tertentu, sementara masih adanya kemelaratan di pihak lain. ${ }^{46}$

\section{Metodologi Penelitian}

Penelitian yang akan peneliti lakukan adalah penelitian lapangan (field research), yaitu secara rinci terhadap suatu subjek tertentu dan satu kumpulan dokumen. Penelitian ini menggunakan penelitian kualitatif yang diperoleh peneliti berdasarkan data di lapangan, yaitu Lembaga Amil Zakat Nurul Hayat Medan dengan menggunakan pendekatan kualitatif-deskriptif. ${ }^{47}$ Lokasi Penelitian ini berada di jalan Ringroad No.18 G Medan Sunggal. Pemilihan tempat penelitian didasarkan kepada pertimbangan penelitian di Lembaga Amil Zakat Nurul Hayat masih sedikit, sehingga peneliti tertarik untuk meneliti di Lembaga Amil zakat Nurul Hayat. Waktu penulisan dan penyusunan tesis ini dimulai dari Maret 2018 hingga selesai. Sumber data yang digunakan dalam penelitian ini adalah dengan menggunakan data Primer yang diperoleh dari hasil survei, pengamatan dan melakukan wawancara mendalam dan data sekunder dari sumber-sumber seperti buku, jurnal, laporan keuangan Nurul Hayat, dan lainnya. 


\section{Hasil Penelitian Dan Pembahasan}

Jumlah Dana ZIS

Tabel 1 Jumlah Dana ZIS Nurul Hayat Tahun 2017

\begin{tabular}{|c|l|c|}
\hline No & \multicolumn{1}{|c|}{ Bulan } & Jumlah ZIS (Rp. Juta) \\
\hline 1 & Januari & 60.393 .736 \\
\hline 2 & Februari & 48.534 .005 \\
\hline 3 & Maret & 57.206 .235 \\
\hline 4 & April & 63.621 .798 \\
\hline 5 & May & 66.752 .095 \\
\hline 6 & Juni & 89.565 .170 \\
\hline 7 & Juli & 59.319 .483 \\
\hline 8 & Agustus & 61.923 .381 \\
\hline 9 & September & 72.534 .558 \\
\hline 10 & Oktober & 75.696 .110 \\
\hline 11 & November & 57.681 .795 \\
\hline 12 & Desember & 94.387 .615 \\
\hline & Total & $\mathbf{8 0 7 . 6 1 5 . 9 8 1}$ \\
\hline
\end{tabular}

Sumber: Laporan Keuangan Nurul Hayat Tahun 2017.

Ketika donatur bertambah setiap tahunnya artinya ada peningkatan juga pada jumlah dana yang dihimpun setiap tahunnya. Peneliti mengamati dana ZIS Nurul Hayat pada tahun 2017. Pada tabel Laporan keuangan yang dari Nurul Hayat menjelaskan bahwa setiap bulannya mengalami berubah-ubah jumlah dana yang terhimpun dikarenakan ada beberapa donator yang cuti atau sudah tiak aktif lagi. Karena dana tersebut kebanyakan donator yang memberi dalam bentuk akad infak. Kalau infak atau sedekah itu tidak ada pemaksaan, asalkan donaturnya itu ikhlas memberi dananya. Walaupun begitu, bukan berarti dana ZIS setiap tahun di Nurul Hayat tidak mencapai target. Mencapai target sesuai dengan pernyataan dari kepala cabang Nurul Hayat karena $15 \%$ dari jumlah tahun sebelumnnya. Akan tetapi masih perlu ditingkatkan lagi khususnya untuk menghimpun dana ZIS.

Dalam tabel laporan keuangan yang peneliti peroleh, dapat dijelaskan bahwa jumlah dana pada tahun 2017 adalah Rp. 807 juta. Sementara pada tahun 2016 dana ZIS nya berjumlah sekitar Rp. 655 jutaan. Artinya adalah peningkatan dana ZIS di LAZ Nurul Hayat pada tahun 2017 daripada tahun 2016. Pada tahun 2017 adanya perbedaan jumlah dana ZIS setiap bulannya. Dari data di atas dapat 
disimpulkan bahwa pada dana ZIS terbesar LAZ Nurul Hayat pada tahun 2017 adalah pada bulan Desember sebesar 94.387.615 juta. Sementara dana ZIS terkecil pada tahun 2017 bulan Februari. Dalam penghimpunan dana ZIS nya tahun 2017 mencapai Rp807 juta, artinya adanya penimgkatan sebesar 152 dari tahun 2016 yang hanya sekitar 655 .

\section{Program}

Tabel 2 Program Kegiatan LAZ Nurul Hayat

\begin{tabular}{|c|c|c|c|c|c|}
\hline No. & Dakwah & Ekonomi & Kesehatan & $\begin{array}{c}\text { Sosial } \\
\text { Kemanusiaan }\end{array}$ & Pendidikan \\
\hline 1 & Matabaca & $\begin{array}{l}\text { Pilar } \\
\text { Mandiri }\end{array}$ & $\begin{array}{l}\text { Praktis } \text { (klinik } \\
\text { medis) }\end{array}$ & Sigab & Sayang \\
\hline 2 & Ibuqu & $\mathrm{BMT}$ & Sahabat & Surga Desa & $\begin{array}{ll}\text { Sahabat } & \text { Muda } \\
\text { Genpres } & \end{array}$ \\
\hline 3 & Tafaqur & $\begin{array}{l}\text { Bantuan } \\
\text { Usaha Untuk } \\
\text { Dhuafa }\end{array}$ & Taawwun (hrd) & $\begin{array}{l}\text { Bencana } \\
\text { Kemanusiaan } \\
\text { (Konflik dan } \\
\text { Perang) }\end{array}$ & SAS \\
\hline 4 & Sahabat Masjid & $\begin{array}{l}\text { Warung } \\
\text { Berkah }\end{array}$ & Khitan massal & Gharim & $\begin{array}{l}\text { Beasiswa Sekolah } \\
\text { Da'i }\end{array}$ \\
\hline 5 & $\begin{array}{l}\text { Aqiqoh } \\
\text { Dakwah Desa }\end{array}$ & - & - & $\begin{array}{lr}\text { Bantuan } & \text { Fakir } \\
\text { Miskin } & \text { (Janda } \\
\text { Dhuafa) } & \end{array}$ & $\begin{array}{ll}\text { Beasiswa } & \text { SMP } \\
\text { Khairunnas } & \end{array}$ \\
\hline 6 & Bunda Yatim & - & - & $\begin{array}{l}\text { Ambulan dan } \\
\text { Jenazah } \\
\text { Terpadu }\end{array}$ & $\begin{array}{l}\text { Beasiswa S1 } \\
\text { Hafidz Dhuafa }\end{array}$ \\
\hline 7 & $\begin{array}{l}\text { Sahabat } \\
\text { Muallaf }\end{array}$ & - & - & Dana Sosial & Beasiswa KEPQ \\
\hline 8 & Dakwah Center & - & - & $\begin{array}{l}\text { Bingkisan } \\
\text { ramadhan }\end{array}$ & Beasiswa PTQ \\
\hline 9 & Takjil & - & - & Qurban Salur & $\begin{array}{l}\text { Pesantren } \\
\text { Mahasiswa }\end{array}$ \\
\hline 10 & $\begin{array}{l}\text { Program } \\
\text { Ramadhan } \\
\text { (I'tikaf, dll) }\end{array}$ & - & - & - & - \\
\hline 11 & $\begin{array}{l}\text { Apresiasi } \\
\text { Karyawan } \\
\text { (GIS) }\end{array}$ & - & - & - & - \\
\hline 12 & $\begin{array}{l}\text { Operasional } \\
\text { Program }\end{array}$ & - & - & - & - \\
\hline 13 & Media & - & - & - & - \\
\hline 14 & $\begin{array}{l}\text { Layanan } \\
\text { Dakwah } \\
\text { (Humas) }\end{array}$ & - & - & - & - \\
\hline
\end{tabular}

Program adalah hal yang sangat harus dibuat oleh setiap lembaga amil zakat. Dengan adanya program, sistem pendistribusian dapat dilakukan oleh 
lembaga Amil Zakat Nurul Hayat. Program ini direncanakan dan dilakukan sesuai dengan visi dan misi dari lembaga Amil Zakat itu sendiri. Nurul Hayat banyak membuat program yang telah direncanakan sesuai dengan visi dan misi seperti Program pendidikan, dakwah, sosial, dan ekonomi. Tetapi untuk program yang telah dilakukan Nurul Hayat pada tahun 2017 yang mengarah kepada memperdayakan ekonomi mustahiknya adalah hanya ada satu program yaitu 'Warung Berkah'. Selebihnya program lainnya lebih kepada program yang bersifat konsumtif.

Dari program yang ada, peneliti menemukan bahwa pada tahun 2017 dari Program rutin yang dilakukan Nurul Hayat hanya satu program rutin yang dapat meningkatkan ekonomi duafanya, yaitu warung berkah. Peningkatan duafa yang dimaksud adalah peningkatan nilai ekonominya yang setelah dibantu adanya kemandirian atau peningkatannya dengan harapan bisa menjadi muzaki, seperti Nenek Salma penerima program dari Warung berkah yang kini telah menjadi muzaki di Nurul Hayat.

\section{Cara Penghimpunan ZIS di Nurul Hayat}

Nurul Hayat merupakan lembaga amil zakat sebagai sarana penyaluran dana zakat, Infak dan sedekah dengan berbagai program seperti, agama, pendidikan, sosial, kesehatan dan pemberdayaan ekonomi yang bertujuan untuk pendistribusian kepada mustahik yang telah ditetapkan untuk memenuhi kebutuhan hidup dan meningkatkan ekonomi mustahik tersebut.

Untuk sistem penghimpunan dana ZIS dari muzaki seperti yang tertera di form pendaftaran yang terlampir di lampiran yang menjelaskan jenis pengambilan pengumpulan dana ZIS di Nurul Hayat yang telah disepakati awal ketika mengisi form pendaftaran. LAZ Nurul Hayat memiliki beberapa cara untuk mempermudah donator dalam memberikan dana kepada lembaga amil zakat. Adapun di LAZ Nurul Hayat memiliki 3 cara dalam proses penghimpunan ZIS diantara yaitu :

1) Dengan cara via Amil.

Maksudnya ialah setiap bulannya amil dari LAZ Nurul Hayat akan datang ke tempat donatur yang dikehendaki sesuai dengan keberadaan donatur saat itu. Ketika amil LAZ Nurul Hayat ingin mengutip dana dari donatur, amil terlebih dahulu menghubungi donatur untuk memastikan keberadaannya dimana karena 
biasanya jika tidak dihubungi bisa saja donatur yang ingin di datangi amil sedang tidak ada di rumah atau bahkan sudah pindah rumah. Untuk itu amil terlebih dahulu menghubungi donatur untuk mengambil dana yang telah disepakati berupa dana zakat, infak ataupun sedekah yang telah disepakati di awal pendaftaran. Petugas akan memberikan slip bukti sebagai dana zakat, infak atau sedekah kepada donatur. Slip ini berfungsi agar transparansi dalam bertransaksi dan menjaga agar data penginputan dana masuk dan keluar sama jumlahnya.

2) Via transfer antar bank.

Maksudnya ialah bagi donatur yang tidak bisa terjangkau lokasinya dari LAZ Nurul Hayat Medan tetapi ingin menjadi bagian orang yang berdonasi di LAZ Nurul Hayat seperti berada di luar Medan seperti binjai, deli serdang, dan lainnya. Maka donatur bisa memilih opsi ini untuk pengumpulan dana di LAZ Nurul Hayat. Via transfer juga bertujuan untuk memudahkan donator dalam berzakat, berinfak ataupun bersedekah dengan praktis dan cepat. Donatur bisa mentrasfer ke bank-bank yang telah bekerja sama oleh LAZ Nurul Hayat akan tetapi lebih diutamakan untuk mentransfer ke Bank Syariah. Adapaun nama-nama bank yang bisa ditansfer oleh donatur yaitu : Bank Mandiri Syariah, BNI Syariah, Bank CIMB Niaga Syariah, Bank Mega Syariah, BRI Syariah, Bank Muamalat, Bank BCA dan Bank Mandiri. Donatur bisa mentransfer dana ke bank tersebut dan mengkonfirmasi dana yang setelah ditransfer ke amil atau bagian administrasinya. Kemudian untuk giftnya berupa majalah, maka diantar melalui kantor pos atau melalui marketing yang jalannya terjangkau oleh marketing tersebut.

\section{3) Via datang ke LAZ Nurul Hayat}

Maksudnya ialah donatur datang ke kantor Nurul Hayat untuk penyerahan dana ZIS rutin setiap bulannya. Akan tetapi via datang ke Nurul Hayat kurang diminati oleh donatur dikarenakan waktu serta lokasi yang terbatas untuk datang ke kantor LAZ Nurul Hayat. Tetapi ada juga bagi masyarakat ataupun donator tetap yang apabila mendapatkan rezeki lebih maka bisa langsung datang ke LAZ Nurul Hayat di luar dari pengutipan secara rutin tiap bulannya.

Dari hasil pengamatan peneliti donator lebih dominan memilih untuk dijemput dananya langsung ketempat keberadaan donator dan via transfer bank 
karena beberapa alasan yaitu karena keterbatasan waktu dan jarak. Untuk pengutipan dana via amil zakat karena pihak donator lebih terfasilitasi dengan adanya penjemputan dana dari amil zakat Nurul Hayat. Hal ini memfungsikan tugas dari amil zakat itu sendiri yaitu sebagai pengumpulan dana ZIS dari masyarakat berupa zakat, infak dan sedekah. Apabila ada donator yang tidak bisa memberikan dananya dalam sebulan atau dua bulan maka dianggap cuti.

Untuk memaksimalkan cara penghimpunan tersebut hasil pengamatan yang peneliti lakukan di LAZ Nurul Hayat, peneliti mengambil kesimpulan bahwa sebagai berikut :

1) Kepala cabang mengangkat dan menungasi beberapa orang amil yang berprofesi sebagai marketing untuk menghimpun dana ZIS

2) Amil yang berprofesi sebagai marketing akan mensosialisaikan dan mempromosikan program-program yang ada di Nurul Hayat untuk memperkenalkan kepada masyarakat sehingga menjadi daya tarik bagi mereka dan nantinya diharapkan bisa menjadi muzaki di Nurul Hayat.

3) Untuk menambah semangat donatur dalam berzakat, berinfak dan bersedekah Nurul Hayat memberikan gift berupa Majalah Nurul Hayat yang berisi tentang cerita hikmah, yang di dalam majalah tersebut juga ada informasi tentang pendistribusian maupun jumlah dana yang terhimpun di Nurul Hayat. Majalah tersebut diberikan kepada semua muzaki yang sudah terdaftar sebagai donator di Nurul Hayat.

4) LAZ Nurul Hayat bersinergi dengan komunitas-komunitas dan membuka stand - stand di acara tertentu serta mempromosikan Nurul Hayat dengan tujuan untuk mendapatkan muzaki lebih banyak. Semakin banyaknya jumlah muzaki, maka semakin banyak juga jumlah dana yang terkumpul nantinya.

5) Amil yang berprofesi sebagai fundraising akan mengirim pesan kepada donator melalui sosial media baik itu via sms, whatsapp atau telepon langsung kepada semua donator yang sudah tercatat sebagai muzaki.

6) Mendahulukan mengirim pesan tersebut kepada donator yang mempunyai gaji tetap karena biasanya pada awal bulan donator yang berprofesi sebagai dosen, pengawai, guru biasanya di awal bulan sudah gajian. Sehingga mudah untuk memberikan dan menyisihkan dana ZIS nya.

\section{Upaya Pendistribusian Untuk Meningkatkan Ekonomi Duafa}


Adapun upaya pendistribusian menurut hasil wawancara dengan Kepala Cabang maupun amil yang ada di Nurul Hayat adalah sebagai berikut:

1) Amil Nurul Hayat yang berprofesi sebagai staf program memilih mustahik dan mendata melalui survei langsung kerumah mustahiknya. Khusus untuk mustahik pemberdayaan ekonomi, pilih yang memiliki skill untuk bisa berusaha dengan adanya bantuan yang diberikan.

2) Apabila mustahik tersebut dinyatakan sebagai mustahik yang layak dibantu atau layak dibantu khusus, maka pihak amil Nurul Hayat akan menghubungi mustahik tersebut bahwa Nurul Hayat akan membantunya. Setelah itu mustahik akan menandatangi kontrak seseuai kesepakatan.

3) setelah penandatangan kontrak maka pihak amil Nurul Hayat akan memberi bantuannya sesuai dengan yang dibutuhkan mustahik tersebut. Untuk progam beasiswa yatim, Iuran Bulanan untuk guru mengaji maupun sahabat muda bisa mengambil langsung bantuannya ke kantor Nurul Hayat. Untuk program seperti warung berkah dan santunan Janda Duafa pihak amil yang akan langsung mendatangi mustahik tersebut untuk member dana bantuannya.

4) setelah itu untuk pendistribusian yang konsumtif adanya laporan kegiatan mengajar seperti IBUQU yang meliputi absensi guru dan murid, foto kegiatan serta data-data murid. Untuk beasiswa yatim dan Sahabat Muda (GenPres) adanya laporan mentoring dan mengaji perpekan. Sementara itu untuk warung berkah adanya laporan penjualan dan pemasukan oleh mustahik tersebut. Khsuus untuk Santunan janda duafa tidak adanya laporan karena janda duafa ini termasuk golongan orang yang sudah lanjut usia.

5) Amil Zakat akan memonitoring sejauh mana perkembangan dengan bantuan dana produktif yang diberikan oleh Nurul Hayat apakah ada peningkatan atau tidak. Jika sudah ada peningkatan apalagi sudah bisanya menjadi seorang muzaki atau donator, maka bantuan tersebut akan digulirkan ke mustahik yang lainnya yang membutuhkan.

\section{Strategi dalam Peningkatan Ekonomi Duafa}

Seperti yang telah dijelaskan oleh Kepala Cabang Nurul Hayat, strategi yang mereka gunakan sama seperti strategi membuka bisnis. Pada LAZ Nurul Hayat pertama kali dilihat adalah pengamatan lingkungan. 
1) Pengamatan lingkungan pada Nurul Hayat adalah melalui survei dan melihat masyarakat mana yang bisa dijadikan mstahik yang benar-benar bisa dibantu untuk diberi dana bantuan dari Nurul Hayat Sendiri.

2) Perumusan Strategi

3) Implementasi Stategi

Pemberdayaan ekonomi duafa di Nurul Hayat dilakukan dengan cara pemantauan. Pemantauan disini adalah mengunjungi langsung ke rumah mustahiknya sepekan sekali. Untuk pengembangan ekonomi mustahik di LAZ Nurul Hayat sendiri ialah dengan adanya salah satu program dari LAZ yaitu adanya warung berkah. Dengan adanya warung berkah yaitu warung yang modal usahanya di subsidi oleh Nurul Hayat dan memberikan makanan gratis bagi para kaum duafa setiap hari jumat. Pengembangan ekonominya ialah kepada si penjual warung berkah tersebut akan mendapatkan keuntungan dari modal yang telah LAZ Nurul Hayat berikan akan tetapi tetap setiap harinya memiliki catatan laporan keuangan yang harus dimiliki si penjual warung berkah tersebut agar termanajeman keuangannya apakah untung atau malah rugi.

Untuk warung berkah sendiri, yang satu-satunya program ekonomi yang telah dibuat oleh Nurul Hayat, bisa dikatakan cukup berhasil dengan pengembangan ekonomi mustahik karena adanya peningkatan ekonomi setelah dibantu oleh Nuurl Hayat dengan harapan bisa mandiri dari sisi ekonominya dan bisa menjadi donator ataupun muzaki.

Bantuan dari Nurul Hayat diberikan setiap hari jumat. Untuk jadwal pemantauanya setiap seminggu sekali ke rumah nenek Salma, pemilik warung berkah tersebut. Biasanya jadwalnya juga tidak ditentukan. Dengan pemantauan setiap pekan, merupakan salah satu upaya dari Nurul Hayat untuk membimbing mustahik penerima bantuan warung berkah ini. Pembimbingan ini juga berguna sebagai sarana pemberdayaan ekonomi yang telah diberi dana bantuannya untuk menciptakan mustahik yang mandiri setelah diberi bantuan.

1) Pemantauan

Pemantauan ini bertujuan untuk sebagai bahan informasi bagi Nurul Hayat untuk mengetahui sejauh mana perkembangan usaha mustahik, selain itu juga untuk mengetahui apakah dana bantuannya dapat dimanfaatkan dengan baik oleh mustahik tersebut dan yang terakhir pemantauan bukan hanya berupa usaha tapi 
juga adanya pemantauan ibadah. Apakah ibadah shalatnya rajin atau malah rajin setelah diberi bantuan.

2) Pembimbingan

Pembimbingan disini adalah adanya arahan untuk mustahik agar melakukan usahanya dengan baik. Apabila mustahik mengalami kesulitan dalam usahanya maka Nurul Hayat akan memberikan solusi untuk bisa membangun usahanya dengan lebih baik.

3) Motivasi

Motivasi adalah suatu dorongan berupa pernyataan yang dilakukan oleh Nurul Hayat sebagai wujud mencapai visi dan misi program dari Nurul Hayat. Motivasi ini bertujuan untuk menambah semangat dari dalam diri mustahik untuk tetap bersemangat apabila ada kendala dalam usahanya

\section{4) Evaluasi}

Setelah adanya implementasi maka adanya evaluasi. Evaluasi ini menjadi bahan pertimbangan Nurul Hayat untuk melihat apakah mustahik yang diberi bantuan ekonominya meningkat atau belum. Selain itu gunanya evaluasi juga menjadi bahan pertimbangan dan masukan Nurul Hayat untuk kedepannya. Seperti Nenek Salma, penerima bantuan program warung berkah yang kini berhasil menjadi mustahik yang mandiri.

\section{Kesimpulan}

Pembahasan mengenai analisis pengelolaan ZIS untuk peningkatan ekonomi duafa sudah peneliti paparkan di dalam tesis ini. Dari pembahasan tersebut peneliti dapat mengambil kesimpulan sebagai berikut:

1. Cara Nurul Hayat dalam menghimpun dana ZIS dengan 3 cara yaitu, pertama dengan cara amil menjemput langsung ke tempat muzaki yang terdaftar sebagai donator, yang kedua, muzaki mentransfer ke rekening Nurul Hayat, dan yang ketiga muzaki langsung datang ke kantor Nurul Hayat.

2. Upaya dalam pendistribusian ZIS di Nurul Hayat dilakukan dengan cara survei langsung para mustahik yang diprogramkan untuk diberi bantuan, dengan memilih dua katagori yaitu layak dibantu dan layak dibantu secara khusus. Hal itu dilakukan untuk menentukan bentuk bantuan sehingga sesuai dengan skill yang dimiliki oleh mustahik yang dipilih. 
3. Strategi yang dilakukan Nurul Hayat adalah dengan cara pemantauan perkembangan usaha yang dilakukan oleh mustahik yang diberi dana ZIS dengan cara mengawasi dan membimbing apabila terjadi kesulitan dalam mengembangkan usahanya.

Berdasarkan kesimpulan di atas, maka saran-saran yang dapat diberikan adalah Nurul Hayat Cabang Medan sebaiknya menambah lebih banyak edukasi program pemberdayaan ekonomi dalam pendistribusian mustahiknya untuk meningkatkan ekonomi duafa dan juga sebaiknya lebih banyak bersinergi dengan perusahan dan instansi lainnya untuk meningkatkan kepercayaan terhadap LAZ Nurul Hayat.

\section{Catatan}

${ }^{1}$ Muhammad, Lembaga Keuangan Mikro Syariah, (Yogyakarta: Graha Ilmu, cetakan 1, 2009) h. 58

${ }^{2}$ Ibid, h. 63

${ }^{3}$ BAZNAS, Outook Zakat Indonesia 2018,(Jakarta: Puskas Baznas, 2007) h. 2

${ }^{4}$ www.bps.go.id di akses pada tanggal 15 Februari 2018

${ }^{5}$ BAZNAS, Outlook Zakat 2017, (Jakarta: PuskasBaznas, 2016 ), h. 6

${ }^{6}$ Ibid

${ }^{7}$ www.bps.go.id di akses pada tanggal 15 Februari 2018

${ }^{8}$ www.wartaekonomi.co.id rilis pada tanggal 12/10/2017 di akses pada tanggal 17 Februari 2108

${ }^{9}$ Didin Hafidhuddin, Agar Harta Berkah dan Bertambah, cet.1. (Jakarta: Gema Insani, 2010), h. 68.

${ }^{10}$ Mustafa Edwin Nasution,et.all, Pengenalan Eksklusif Ekonomi Islam (Jakarta : Kencana, Cet. 3. 2010), h. 208.

${ }^{11}$ Muhummad B Yusuf, Zakat, Infak dan Sedekah Expenditure, and Economic Growth in Malaysia, Internasional Journal of Business and Social Science, Vol 2 No 6, April 2011, h. 175181

${ }^{12}$ Muhammad Azam, et.all, Zakat,Infak dan Sedekah and Economic Development : Micro dan Macro Level Evidence jurnal Bulletin of Bussines and Economic,Pakistan: 2014, h. 85-95

${ }^{13}$ Baznas, Outlook Zakat 2018, (Jakarta, Puskas Baznas, 2017) h. 32

${ }^{14}$ Abdurrachman Qadir. Zakat, Infak dan Sedekah : Dalam dimensi Mahdhah dan Sosial, (Jakarta: Raja Grafindo Persada. 2001), h. 83-84.

${ }^{15}$ Undang-Undang Republik Indonesia Nomor 23 Tahun 2011 Tentang Pengelolaan Zakat, Infak dan Sedekah

${ }^{16}$ Agus Thayib Afifi dan Shabira Ika, Kekuatan Zakat: Hidup Berkah Rezeki Berlimpah, (Yogjakarta: Pustaka Albana, 2010) h.1

${ }^{17}$ Yusuf Qardhawi, Figh Az-Zakah. terj. Salman Harun dkk, Hukum Zakat, Cetakan 7, (Jakarta: Pustaka Litera Antarnusa, 2004), h. 34

${ }^{18}$ Amiruddin Inoed, dkk. Anatomi Fiqh Zakat : Potret \& Pemahaman Badan Amil Zakat Sumatera Selatan. (Yogyakarta : Pustaka Pelajar, 2005), h. 9

${ }^{19} \mathrm{Ibid}, \mathrm{h} .12$

${ }^{20}$ Mardani, Aspek Hukum Lembaga Keuangan Syariah di Indonesia, (Jakarta: Kencana, 2015) h. 399

${ }^{21}$ Nurul Huda, Lembaga Kenangan Islam: Tinjauan Teoritis dan Praktis, (Jakarta: Kencana, 2010) h. 293

${ }_{22}$ Al-Muyassar, Al-Qur'an dan Terjamahannya juz 1s/d 30, (Bandung: Sinar Baru Algensindo, 2013), h. 1351

${ }^{23}$ Muhammad bin Ismail bin Ibrahim bin Mughirah bin Bardizbah al-Ju'fi al-Bukhari, $A l$ Jami' as-Sahih al-Bukhari (Beirut: Dar al-Fikr, Juz 1, 1989), h. 80. 
${ }^{24}$ Wahbah Az-Zuhaili, Fiqhuz Zakah, terj. A. Aziz Masyhuri, Fiqih Zakat Dalam Dunia Modern (Surabaya: Bintang, cet.1, 2001), h. 7

${ }^{25}$ Didin Hafidhuddin, Panduan Praktis tentang Zakat, Infak, dan Sedekah, (Jakarta : Gema Insani, 1998), h. 14

${ }^{26}$ Amiruddin, Anatomi Fiqh Zakat,...h. 13

${ }^{27}$ Beni kurniawan, Manajeman sedekah, (Tangerang: Jelajah Nusa, t.t.P) h. 19

${ }^{28}$ UU Nomor 23 Tahun 2011 tentang Pengelolaan Zakat

${ }^{29}$ Al-Muyassar, Al-Qur'an dan Terjamahannya juz 1s/d 30,...h. 128

${ }^{30}$ Muhammad Hasan, Manajemen Zakat: Model Pengelolaan yang Efektif, (Yogyakarta: Idea Press, 2011),h.3

${ }^{31}$ Muhammad Hasan, Manajemen Zakat: Model Pengelolaan yang Efektif, (Yogyakarta: Idea Press, 2011), h.3

${ }^{32}$ Al-Muyassar, Al-Qur'an dan Terjamahannya juz 1 s/d 30,... h. 79

${ }^{33}$ Ibid, h.350

${ }^{34} \mathrm{Ibid}$, h. 381

${ }^{35}$ Ilyas Supena dan Darmuin, Manajemen Zakat, (Semarang: Walisongo Press, 2009), h.

${ }^{36}$ Ibid, h. 301

37 Andri Soemitra, Bank dan Lembaga Keuangan Syariah (Jakarta: Kencana Prasada, 2009), h. 426

${ }^{38}$ Ibid, h. 427

${ }^{39}$ Warkum Sumitro, Perkembangan Hukum Islam di Tengah kehidupan Sosial Politik di Indonesia, Cet 1. (Jawa Timur: Bayu Media) h. 229

${ }^{40}$ Sardi Karjoredjo, Desentralisasi Pembangunan Daerah di Indonesia.( Salatiga: FEUKSW, 1999), h.35

${ }^{41}$ Sadono Sukirno, Makroekonomi : Teori Pengantar, Edisi Ketiga. (Jakarta: Rajawali Pers, 2012) h.29

${ }^{42}$ Eko Prasetyo. Fundamental Makro Ekonomi. (Yogyakarta: Beta Offset. 2009), h.237

${ }^{43}$ Sauqi Ismail Sahhatih, Penerapan Zakat Dalam Bisnis Modern, (Bandung:Pustaka Setia, 2007) h. 83

${ }^{44}$ Indonesia Zakat \& Development Report, 2011, Kajian Empiris Peran Zakat Dalam Pengentasan kemiskinan, Ciputat, Indonesia Magnificence of Zakat (IMZ), h.9

${ }^{45}$ Ibid, h. 10

${ }^{46}$ Muhammad bin Shalih Al-Utsaimin, Fiqh Zakat Kontemporer, (Solo, Al-Qowam: 2011), h.13.

${ }^{47}$ Lexy J. Moleong, Metode Penelitian Kualitatif, (Jakarta: Rosda Karya, 2014), h.156.

\section{Daftar Pustaka}

Afifi, Agus Thayib dan Shabira Ika. 2010. Kekuatan Zakat: Hidup Berkah Rezeki Berlimpah. Yogjakarta: Pustaka Albana'

al-Bukhari, Muhammad bin Ismail bin Ibrahim bin Mughirah bin Bardizbah alJu'fi. 1989. Al-Jami' as-Sahih al-Bukhari. Beirut: Dar al-Fikr, Juz 1.

Al-Muyassar. 2013. Al-Qur'an dan Terjamahannya juz 1s/d 30. Bandung: Sinar Baru Algensindo.

Al-Utsaimin, Muhammad bin Shalih. 2011. Fiqh Zakat Kontemporer. Solo, AlQowam.

Azam, Muhammad, et.all, Zakat, Infak dan Sedekah and Economic Development : Micro dan Macro Level Evidence jurnal Bulletin of Bussines and Economic, Pakistan: 2014. 
Az-Zuhaili, Wahbah. 2001. Fiqhuz Zakah, terj. A. Aziz Masyhuri, Fiqih Zakat Dalam Dunia Modern. Surabaya: Bintang, cet.1.

BAZNAS, 2016. Outlook Zakat 2017. Jakarta: Puskas Baznas.

BAZNAS, 2007. Outook Zakat Indonesia 2018. Jakarta: Puskas Baznas.

Hafidhuddin, Didin. 1998. Panduan Praktis tentang Zakat, Infak, dan Sedekah. Jakarta : Gema Insani.

2010. Agar Harta Berkah dan Bertambah, cet.1. Jakarta:

Gema Insani

Hasan, Muhammad. 2011. Manajemen Zakat: Model Pengelolaan yang Efektif. Yogyakarta: Idea Press.

Huda, Nurul. 2010. Lembaga Keuangan Islam: Tinjauan Teoritis dan Praktis. Jakarta: Kencana.

Indonesia Zakat \& Development Report, 2011, Kajian Empiris Peran Zakat Dalam Pengentasan kemiskinan, Ciputat, Indonesia Magnificence of Zakat (IMZ).

Inoed, Amiruddin, dkk. 2005. Anatomi Fiqh Zakat : Potret \& Pemahaman Badan Amil Zakat Sumatera Selatan. Yogyakarta : Pustaka Pelajar.

Karjoredjo, Sardi. 1999. Desentralisasi Pembangunan Daerah di Indonesia. Salatiga: FE-UKSW.

Kurniawan, Beni. Manajeman sedekah. Tangerang: Jelajah Nusa.

Mardani, 2015. Aspek Hukum Lembaga Keuangan Syariah di Indonesia. Jakarta: Kencana.

Moleong, Lexy J. 2014. Metode Penelitian Kualitatif . Jakarta: Rosda Karya.

Muhammad. 2009. Lembaga Keuangan Mikro Syariah. Yogyakarta: Graha Ilmu, cetakan 1 .

Nasution, Mustafa Edwin, et.all. 2010. Pengenalan Eksklusif Ekonomi Islam. Jakarta : Kencana, Cet. 3.

Prasetyo, Eko. 2009. Fundamental Makro Ekonomi. Yogyakarta: Beta Offset.

Qadir, Abdurrachman. 2001. Zakat, Infak dan Sedekah : Dalam dimensi Mahdhah dan Sosial. Jakarta: Raja Grafindo Persada.

Qardhawi, Yusuf. 2004. Fiqh Az-Zakah. terj. Salman Harun dkk, Hukum Zakat, Cetakan 7. Jakarta: Pustaka Litera Antarnusa. 
184 | AT-TAWASSUTH: Volume IV No. 1 Januari - Juni 2019: 160 - 184

Sahhatih, Sauqi Ismail. 2007. Penerapan Zakat Dalam Bisnis Modern. Bandung:Pustaka Setia.

Soemitra, Andri. 2009. Bank dan Lembaga Keuangan Syariah. Jakarta: Kencana Prasada.

Sukirno, Sadono. 2012. Makroekonomi: Teori Pengantar, Edisi Ketiga. Jakarta: Rajawali Pers.

Sumitro, Warkum, Perkembangan Hukum Islam di Tengah kehidupan Sosial Politik di Indonesia, Cet 1. Jawa Timur: Bayu Media.

Supena, Ilyas dan Darmuin. 2009. Manajemen Zakat. Semarang: Walisongo Press.

Undang-Undang Republik Indonesia Nomor 23 Tahun 2011 Tentang Pengelolaan Zakat, Infak dan Sedekah.

UU Nomor 23 Tahun 2011 tentang Pengelolaan Zakat.

www.bps.go.id di akses pada tanggal 15 Februari 2018.

WwW.wartaekonomi.co.id rilis pada tanggal 12/10/2017 di akses pada tanggal 17 Februari 2018.

Yusuf, Muhummad B. Zakat, Infak dan Sedekah Expenditure, and Economic Growth in Malaysia, Internasional Journal of Business and Social Science, Vol 2 No 6, April 2011. 